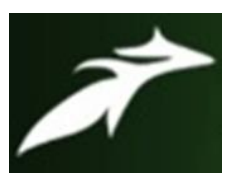

Anshumali et al, International Journal of Advances in Agricultural Science and Technology,

Vol.8 Issue.7, July-2021, pg. 34-42

ISSN: 2348-1358

Impact Factor: 6.057

NAAS Rating: 3.77

\title{
Impact of COVID-19 on Agriculture and Allied Sectors
}

\author{
Anshumali ${ }^{1}$; S.K.Sharma ${ }^{2}$; Mittu Katoch ${ }^{3}$; Pawan Pathania ${ }^{4}$ \\ 1. M. Sc Student, 2. Principal Scientist, 3. Senior Research Fellow, 4. Principal Scientist \\ CSKHPKV, Palampur, H.P. \\ Corresponding Author: mitukatoch.katoch@gmail.com \\ DOI: 10.47856/ijaast.2021.v08i7.004
}

\begin{abstract}
Impact of Corona virus outbreak on mankind is serious. Apart from health issues and social life stand still, global economy has been affected drastically. Many sectors have been hit by this pandemic and agriculture and allied sectors are no exception. Issues such as shortage of labour, restricted access to markets have been tremendously affected this sector. Many of its frailties were exposed during the course but the resilient cultivation sector surfaced with some promising results after a good monsoon and aggressive response demonstrated by the government to support the sector. Government excluded several farming activities such as farm operations, agribusiness, dairy, poultry and fishery from lockdown limitations after the lockdown extended in May, 2020.

Pandemic also presented a great opportunity to think over and evaluate the hidden potential of respective sectors. Solemn efforts are required for innovation and technical up gradation of agricultural operations to alleviate the impacts of the COVID-19 pandemic. As India struggles to uplift the distressed economy, government announced economic stimulus package worth INR 20, 00,000 crore under Atma Nirbhar Bharat Campaign. Long term impacts of this campaign are estimated to develop agriculture and allied sectors with major emphasis on quality products and increased exports of agriculture commodities.
\end{abstract}

Keywords: COVID-19, pandemic, Agriculture, lockdown

\section{INTRODUCTION}

The COVID-19 pandemic is one of the most disastrous global health calamity faced by the mankind in this century. This new infectious respiratory disease first emerged in Wuhan, Hubei province, China in December, 2019 and is caused by a new class of corona virus, known as SARS-CoV-2 (Severe Acute Respiratory Syndrome Corona Virus 2). COVID- 19 was declared as a pandemic by World Health Organization (WHO) in January 2020. The virus has spread to more than 200 countries throughout the world, inducing massive economic, 


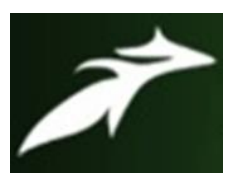

Anshumali et al, International Journal of Advances in Agricultural Science and Technology,

Vol.8 Issue.7, July-2021, pg. 34-42

ISSN: 2348-1358

Impact Factor: 6.057

NAAS Rating: $3 \cdot 77$

environmental, health and social challenges to the entire human population, jeopardizing livelihoods, increasing unemployment, disrupting supply chains, undermining demand and production capacities, thereby affecting the economy. Corona virus outbreak has brought the economy as well as the developmental progress of several nations to a standstill. The global economy is estimated to shrink by over 3\% in 2020, (IMF). Although the challenges remained mostly common across the economy, the impact on each sector varied markedly.

India reported first case of COVID-19 on January 30, 2020 in Kerala subsequently, followed by a nationwide lockdown which impacted the country both economically and socially.

Farm sector in India provides employment to about 800 million people directly and indirectly. Agriculture is the primary source of livelihood for over 58\% of the nation's population and employs $44 \%$ of the workforce. The sector contributes approximately $17.2 \%$ to India's GDP which is more than the manufacturing sector and exhibited a sustained CAGR of $2.1 \%$ between 2014 and 2018. Share of Agriculture is more than 0.52 per cent in the growth proportion of Indian economy. Impact of the lockdown on the Indian agriculture sector varied across different segments of the agricultural value chain and imposed unforeseen challenges to harvest, transportation, logistics, exports and labour availability.

\section{Review of Literature}

$>$ Narayanan (2020), indicated that farmers were stuck with harvest during initial period of lockdown in March as APMC (Agricultural Produce Market Committee) mandis were closed in many states which subsequently led to the disruption in food supply starting from the production to the consumption centres.

$>$ Sahoo \& Rath (2020) in their paper entitled "Potential Impact of Corona Virus on Agriculture Sector" suggested the need for specific rules by legislature for horticulture activity in order to avert the antagonistic effect of Covid-19 pandemic along with keeping the agribusiness section unaffected and to ensure that the smallholders are not under any sort of financial setbacks. Social separating within the cultivating network was required to shield the workers from Corona infection in tandem with managing the frenzy as well as mental misfortunes during this crucial period. Farmers should be provided with a stage or means for direct advertising to address the demands of the shoppers by home conveyance of the farming produce and to put off any kind of wastages in the perishable items. 


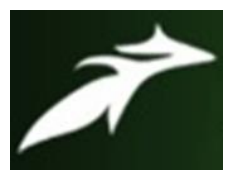

Anshumali et al, International Journal of Advances in Agricultural Science and Technology,

Vol.8 Issue.7, July-2021, pg. 34-42

ISSN: 2348-1358

Impact Factor: 6.057

NAAS Rating: $3 \cdot 77$

Singh et al (2020) carried out a study on Impact of COVID-19 on Agriculture and Allied Sectors and concluded that farmers were affected in several states of the country due to non- availability of labourers, nonetheless, harvesting of major food crops was completed. Pandemic affected the agricultural labourers mostly due to shut down of different activities related to agriculture.

In case of livestock sector, surplus production of milk and reduced availability of feed and concentrate were major affected areas as marketing channels as well as transport facilities were restricted during lockdown although, the government took initiative to exempt marketing with curfew passes. The impact of COVID-19 on horticulture/ floriculture sector was also severe as the harvesting and marketing of major fruit crops was affected. Restriction on exports caused downfall of floriculture industry.

> In a report entitled "COVID-19 Lockdown: Impact on Agriculture and Rural Economy" published by Society for Social and Economic Research, it was realized that agricultural activities such as purchase of inputs, harvesting and marketing of agricultural produce were unprecedentedly disrupted due to sudden and unplanned imposition of nationwide lockdown. Harvesting of wheat faced major disruption due to non- availability of combine harvesters in the villages as inter-state movement of harvesters was restricted. Lack of workers affected the post-harvest operations, such as threshing, winnowing and storage in most of the places. Ranchers who produce fruits, such as litchis, mangoes, melons and watermelons, suffered huge losses because of collapse of domestic demand and restriction of exports. Shortage of cold-storages caused massive losses to the producers of perishable crops such as vegetables and fruits.

Procurement of rabi harvest (wheat) was delayed by several days and, until May 15, only 83 per cent of the total amount of wheat was procured compared to last year, out of which 96 per cent of the procurement happened in 4 states only. Delay in public procurement forced farmers to sell their produce to private traders at prices considerably below MSP.

Rumors associated with the spread of virus through meat and poultry products triggered huge downfall in the demand for poultry products, causing massive losses to poultry farmers. Demand for milk fell by 20-25 per cent all over the country along with decrease in the procurement prices of milk. Informal milkmen as well as private dairies straight away decreased the purchase of milk from dairy farmers, though the cooperatives continued the procurement of milk. 


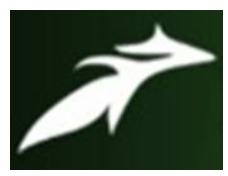

Anshumali et al, International Journal of Advances in Agricultural Science and Technology,

Vol.8 Issue.7, July-2021, pg. 34-42

ISSN: 2348-1358

Impact Factor: 6.057

NAAS Rating: $3 \cdot 77$

> Ramakumar (2020) conducted a comparative study on "Agriculture and the Covid-19 Pandemic with special Reference to India" summed up the results under four categories: production and stock of food, agri-supply chains, prices of agricultural commodities and migrant workers.

India had ample stocks of food grains and pulses to feed its population throughout the period of lockdown. Nevertheless, production had not been a challenge in India since past decades; issues lie in the internal distribution. During the lockdown, millions of people in India endured the reduced food consumption and hunger.

However, situation was different in case of animal products as these are produced and marketed on a daily basis. The obstructions in transporting animals prompted the closure of abattoirs which resulted in reduced supplies of meat. There was a major fall in the demand of milk by 20 to 30 per cent combined with the reduction in the procurement of milk by the cooperatives. Poultry growers were worst hit in the animal sector. The industry began to affect in early February 2020, when rumors started piling up concerning the spread of virus by the consumption of meat and poultry. Sharp decline in the demand for eggs and chicken led to major economic losses in this sector. Millions of birds were culled to cut losses among poultry growers.

During lockdown, there was a total breakdown of supply chains, global and Indian. Worldwide exports of agricultural goods were disapproved. Sowing, harvesting, marketing as well as value addition of crops were in distress. In India, major difficulties endured by the farmers were (a) unavailability of laborers to harvest the rabi crops (b) obstructions in the procurement of food grains by state and government agencies (c) obstructions in the collection of rabi harvests from farms by traders (d) shortage of truck drivers and restriction in the transport (e) limited number of functioning APMC mandis.

Retail prices grew high for certain food items, mainly due to disruptions in the supply chain. Vulnerable sections of the population withstood the limited access to food shrunk with rises in food prices. There was a considerable gap between the prices received by farmers and the prices paid by the consumers due to supply disruption and fall in demand.

The Covid-19 pandemic highlighted the importance of migrant workers in agriculture and allied sectors. Migrant farm workers who have always endured the poor living and working conditions, lack of social security as well as oppressive systems of labour control, 


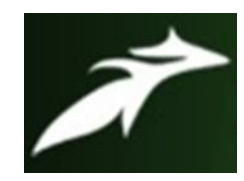

Anshumali et al, International Journal of Advances in Agricultural Science and Technology,

Vol.8 Issue.7, July-2021, pg. 34-42

ISSN: 2348-1358

Impact Factor: 6.057

NAAS Rating: $3 \cdot 77$

were made visible by their absence. Farmers stumbled due to labour shortage, as agricultural operations came to a stand- still and costs of labour rose.

In a report entitled "Decoding agriculture in India amid COVID-19 crisis" published by FICCI (2020), estimated impact of pandemic was assessed on several agri-sectors which included-

Seed sector:

- Anticipated delay in supply of seeds to farmers during Kharif season was a major setback as seed production is dependent on allied sectors such as manpower, transportation and packaging, all of which were impacted due to the lockdown.

- Transport of seeds from manufacturing units to farmers' fields became a big challenge.

- Recurred losses as a consequence of hoarding, storage, salaries and interest led to considerable increase in cost of operations (20-30\%) accompanying limited credit services provided by banks and other institutions in the current financial year.

- Restriction on movement, Lack of plausibility in port, border closures in addition to nonclearance of permits kept seeds exports and imports at standstill.

Agro-chemicals:

- Availability of sufficing domestic inventories lowered the impact of lockdown on agrochemicals for the Kharif season while transportation of the material from factories to farmers remained a major issue.

- Movement of shipments was hindered due to large no. of trucks stopped at state borders.

- Border closure and disruptions of supply chains in China were likely to cause an estimated $10-24 \%$ increase in the cost of raw materials imported from China.

Fertilizers:

- Lockdown had no significant impact on the production, distribution and sales of fertilizers during June and July, as fertilizers are transported by railway wagons which is Govt. controlled.

Farm operations:

- Workforce shortage at procurement centres had a considerable impact on the procurement of harvested crops. 


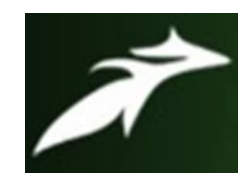

Anshumali et al, International Journal of Advances in Agricultural Science and Technology,

Vol.8 Issue.7, July-2021, pg. 34-42

ISSN: 2348-1358

Impact Factor: 6.057

NAAS Rating: $3 \cdot 77$

- Market arrivals of fruits and vegetables were declined mainly due to difficulties in transportation as most of the small and medium enterprise farmers were incapable to rent an entire truck by themselves.

- Supply of major cereals, fruits and vegetables to mandis were reduced by $55 \%$ instigating significant increase in the retail price of food items for consumers along with considerable decrease in price realizations for growers. Farmers were forced to sell their produce to local traders at lower prices due to supply disruptions accompanied by reduction in demand as a consequence of closure of hotels, restaurants and airlines.

- Fake fear propaganda of spread of infection via poultry products massively impacted the poultry farmers due to reduced demand for poultry products. Farmers had to bear an average loss of Rs.130 per bird during initial spread of pandemic in the country. Distress demand of meat and poultry products led to nearly $40 \%$ decline in maize prices which impacted the farmers in Bihar, Andhra Pradesh and the Northeastern belt where maize is planted as Rabi crop and harvested between April to June.

Farm machinery:

- Inability of farmers to transport their crop to mandis due to transportation hindrances including unavailability of tractors and trucks resulted in wastage of harvested crop in the fields

- Reduced liquidity at farm level and uncertainty of cash flows due to hindered movement of sales officers for documentation and verification work led to de- growth of farm machinery industry.

Micro- irrigation:

- Limited supply of equipment from warehouse stocks during lockdown

- Guidelines issued by Centre and State govt. regarding manufacturing and distribution of various equipment associated with irrigation were inconsistent which resulted in production delays.

- Situation became more worrisome as banks were offering limited credit facilities.

Cold Storage:

- Disconnection of electricity supply due to anticipatable delay in payments might affect the cold-chain units, following the loss of tonnes of food material. 


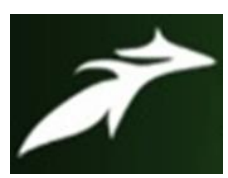

Anshumali et al, International Journal of Advances in Agricultural Science and Technology,

Vol.8 Issue.7, July-2021, pg. 34-42

ISSN: 2348-1358

Impact Factor: 6.057

NAAS Rating: $3 \cdot 77$

- Restrictions on movement might lead to limited use of cold storage units by farmers and traders and would result in quality and value loss of perishable produce such as fruits and vegetables.

Arumugam et al. (2020) in their paper entitled "COVID-19: IMPACT OF AGRICULTURE IN INDIA" reported that agriculture sector which is the spine of our country was hit with the repercussions of Covid-19 flare- up. Restrictions imposed due to lockdown hampered the transport of agriculture commodities from its place of production to the consumer. Fear of viral transmission resulted in the shortage of labour force which consequently led to the wastage of perishable commodities, mainly fruits and vegetables, in the farmer's field itself. Potential effects of COVID-19 pandemic were also seen on the agribusiness item store network which is astounding web of producer, transporter, distributer, retailer and lastly the customer.

Singh et al. (2020) in their paper entitled "Impact of COVID-19 on Agriculture and Allied Sectors" ascertained COVID-19 had shut every boundary as well as economic activities of the nation and brought about the tremendous effect on agriculture and allied sectors, which is the cornerstone of Indian economy. Farmers entered into new normal of life during the lockdown period which was likely to continue in post COVID-19 situation by following the hygiene practices and adopting social distancing in normal life as well as in the field. Livestock farmers were affected by decline in the price of milk and other products, fall in meat production in poultry, fisheries and goatery sector, demand fluctuation of milk and poultry, concentrates, feed and fodder problems in several parts of the country .Agriculture and horticulture sectors faced problems of shortage of manpower for field operations. COVID-19 pandemic impelled the restriction on movement which ultimately led to shutdown of farming units in service and manufacturing sector. By adopting this new normal of life, farmers now need to make use of the e-channel for marketing their farm produce. Government should emphasize on creating awareness for COVID-19 and associated myths alongside the support to farmer by reforming government schemes.

\section{CONCLUSION}

COVID-19 flare-up has detestably surprised the world economy and has had an apathetic insinuation on social life. The most responsive agriculture sector was also hit with the ramifications of Covid-19 pandemic. Lockdown induced the scarcity of labour due to fear of virus transmission, hampered the movement of agriculture commodities to the markets 


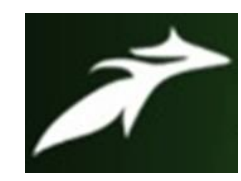

Anshumali et al, International Journal of Advances in Agricultural Science and Technology,

Vol.8 Issue.7, July-2021, pg. 34-42

ISSN: 2348-1358

Impact Factor: 6.057

NAAS Rating: $3 \cdot 77$

which ultimately led to the wastage of perishable commodities such as fruits and vegetables in the farmers' fields itself.

Agriculture sector deserves new policies and reforms in a post-Covid world. The pandemic drew attention to the major loopholes in the existing agricultural policies. It highlighted the importance of self-sufficiency in food production and the drawbacks of free trade arrangement.

Covid-19 crisis has brought up the need for self- reliance in each sector. Catastrophe of the pandemic is likely to have a lasting impact on global supply chains for all agriculture inputs like seeds, fertilizers, agro-chemical products etc. India needs to design its regulatory mechanism to attract foreign investments and emerge stronger post Covid-19 pandemic.

A comprehensive approach is required towards agrarian economy by introducing efficient farm-to-fork delivery models, value addition, improving quality, upgrading agri-logistics and establishing technology framework in rural areas to ensure the production of rich quality food. There is an immediate need for the development of agri-supply chain to link the rural community to urban hubs to achieve fork to farm linkages. In order to enhance the exports of agricultural produce, India needs to accelerate more private investments, ensure the up gradation of value addition of the products and further promote the exports of these products with global certifications. Going forward, India needs to re-design the export policies with greater involvement of state governments and better price realization to the farmers. In a nutshell, we can say that at the other end of the pandemic, struggle still continues.

\section{REFERENCES}

[1]. COVID-19 Lockdown: Impact on Agriculture and Rural Economy, published by Society for Social and Economic Research

[2]. Department of Economic Affairs (2020),"Macroeconomic Report," Economic Division, Government of India, New Delhi, May

[3]. Government of India (GoI) (2020), "Atmanirbhar India: Part 3, Agriculture," Power Point Presentation made by Finance Minister, Government of India, New Delhi, May 15.

[4]. http://ficci.in/spdocument/23267/FICCI-GT-Report-on-Agriculture.pdf 


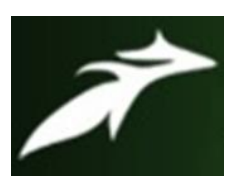

Anshumali et al, International Journal of Advances in Agricultural Science and Technology,

Vol.8 Issue.7, July-2021, pg. 34-42

ISSN: 2348-1358

Impact Factor: 6.057 NAAS Rating: $3 \cdot 77$

[5]. ILO, Sectoral Brief: COVID-19 and the impact on agriculture and food security, April 2020.assesedfromhttps://www.ilo.org/ documents/briefingnote/wcms_742023.pdf.

wcmsp5/groups/public/—ed_dialogue/—sector/

[6]. Impact of COVID-19 on Indian Agribusinesses, 2020 by SAATHI (South Asia Ag Tech Hub for Innovation)

[7]. Indian Express (2020), "Supply chain breaks, farmers in distress", Indian Express, April 1, https://bit.ly/3621IuP.

[8]. Narayanan, Sudha (2020), "Food and agriculture during a pandemic: Managing the consequence", https://www.ideasforindia.in/topics/agriculture/food-and-agriculture-during-apandemic-managing-theconsequences.html

[9]. Prangya Paramita Sahoo \& Suvangi Rath (2020)Potential Impact of Corona Virus on Agriculture Sector, Biotica Research Today, Vol 2:4, www.bioticainternational.com.

[10].Press Information Bureau (PIB) (2020a), "Functional Agricultural Markets Almost Double since Beginning of Lockdown," Ministry of Agriculture and Farmers' Welfare, Government of India, April 23, available at https://pib.gov.in/PressReleasePage.aspx?PRID=1617594.

[11].Press Information Bureau (PIB)(2020b),“200 New Mandis from 7 States Integrated with the eNAM Platform for Marketing of Agricultural Produce," Ministry of Agriculture and Farmers' Welfare, Government of India, May 1, available at https://pib.gov.in/PressReleseDetailm.aspx? PRID=1620050.

[12].Press Information Bureau (PIB)(2020c),““Kisan Rath’ Mobile App Turns Big Hit Within a Week of Its Launch," Ministry of Agriculture and Farmers' Welfare, Government of India, April 24, available at https://pib.gov.in/PressReleasePage.aspx?PRID=1617919.

[13].PTI (2020b),"Indian Begins Export of Major Farm Items Amid COVID-19 Lockdown: Government," The Economic Times, April 15, available at https://economictimes.indiatimes. com/news/economy/foreign-trade/indian-begins-export-of-major-farm-items-amid-covid-19lockdown-government/articleshow/75163423.cms,.

[14].Ramakumar, R. (2020), "Agriculture and the Covid-19 Pandemic: An Analysis with Special Reference to India," Review of Agrarian Studies, vol. 10, no. 1

[15].Singh, A \& Singh, Lakhan \& Kumar, Sunil. (2020). Impact of COVID-19 on Agriculture and Allied Sectors. 8-16.

[16].Singh, Shikha (2020), "India Lockdown: Corn Prices Drop as COVID-19 Takes Toll on Domestic Demand," S\&P Global, April 8, available at https://www.spglobal.com/platts/en/marketinsights/latest-news/agriculture/040820-indialockdown-corn-prices-drop-as-covid-19-takestoll-on-domestic-demand.

[17].Uthandu, Arumugam \& G., Kanagavalli \& Manida, M. (2020). COVID-19: IMPACT OF AGRICULTURE IN INDIA. Aegaeum. 8. 480-488. 